Misr J. Ag. Eng., 26(4): 1682 - 1695

FARM MACHINERY AND POWER

\title{
IDENTIFY SUITABLE HYDRAULIC FACTORS FOR CONTROL RAISE AND LOWER LASER SCRAPERS. \\ ${ }^{1}$ El-Katib, S. I. $\quad{ }^{2}$ Eid, S. F. M. $\quad{ }^{3}$ Osman, H.E. \\ ABSTRACT
}

The present work was carried out in private farm at Hoash Essa - Behera governorate during agriculture season of 2008 in clay soil. The aim of this experiment is to study the relation between the tractor hydraulics, hydro-electric valves, scraper cylinder, raise and lower scraper paled, scraper load and their effects on the laser land leveling efficiency. An area of (6 feddans) was divided into 2 plots; each plot was leveled with different scraper. Two scrapers were used 3 and $3.6 \mathrm{~m}$ width (10 and 12 feet). Each plot was surveyed and calculated the volume of cut $\left(\mathrm{m}^{3}\right)$. The hydraulic of oil pressure (bar) and hydraulic of oil flow rate (l/min) were measured with the scraper raise (every $0.5 \mathrm{~cm}$ ) and computed the volume of soil fill $\left(\mathrm{m}^{3}\right)$. Also, the actual capacity of scrapers volume $\mathrm{m}^{3}$, amount of earth moving $\mathrm{m}^{3} / \mathrm{h}$ and laser efficiency were calculated.

The results showed that, actual scrapers loaded were 69 and $70.50 \%$ (from theoretical loaded) with 3 and $3.6 \mathrm{~m}$ scraper width, respectively. Maximum pressure needed to raise scraper was 52 and 110 bar with 3 and $3.6 \mathrm{~m}$ scraper width, respectively. Maximum oil flow rate was 18.5 and $38.00 \mathrm{l} / \mathrm{min}$. with 3 and $3.6 \mathrm{~m}$ scraper width respectively. Scrapers field capacities were 10.88 and $16.96 \mathrm{~m}^{3} / \mathrm{h}$ with 3 and $3.6 \mathrm{~m}$ scraper width, respectively. Every cubic meter of soil needed to 52 bars and 18.5 l/min. oil flow rate to fill area $25 \mathrm{~m}^{2}$ with $4 \mathrm{~cm}$ depth.

The scraper capacity efficiency increased by increasing cutting depth, it was increased from 6.94 to $69.44 \%$ by increasing cutting depth from 0.5 to $4 \mathrm{~cm}$ for 3 meter scrapers width also it was increased from 4.63 to 70.73\% by increasing cutting depth from 0.5 to $4 \mathrm{~cm}$ for 3.6 meter scrapers width. The predicted equations help engineering computer designers to make decision easily and determine the actual hydraulic oil pressure and oil flow rate to move the amount of earth.

Kay words: The hydraulic oil pressure, oil flow rate, raising and lowering scraper paled.

${ }^{1}$ Senior Res., Agric. Eng., Res. Ins., Agric. Res. Center, MOA, Cairo.
2 Res., Agric. Eng. Res. Ins., Agric. Res. Center, MOA, Cairo.
${ }^{3}$ Deputy, Agric. Eng., Res. Ins., Agric. Res. Center, MOA, Cairo, Egypt. 


\section{INTRODUCTION}



aser is already being used successfully in Egypt for many years. The government of Egypt has introduced the laser controlled leveling of land to reduce the amount of water needed to irrigate the crops. For border irrigation purposes any field is to be considered adequately leveled is at $85 \%$ of random checking points, the difference in its elevation from the average designed elevation does not exceed \pm 15 $\mathrm{mm}$ above level variation proved to be quite convenient for surface irrigation requirements under all conditions. Although, it was previously considered to be a very strict parameter for leveling with manual controlled equipment, its no longer a restrictive tolerance in laser controlled leveling which can definitely achieve much less variation \pm 5 to $\pm 10 \mathrm{~mm}$ has be easily performed in agriculture leveling . Hydro - electric solenoid unit, as initially installed, did not incorporate any flow control valves and was causing very erratic movements in both raise and lower modes, which created inappropriately sharp and continuous on leveled surface. The raise movement and lowering movement smoothed were recommended to give a good finished surface (El—Hammamy (1988)).

Mostafa et al. (1993) concluded that the power requirement for laser land leveling operation was $60.15 \mathrm{hp}$. While for manual (without laser), leveling was $58.36 \mathrm{hp}$ under the same conditions. CPTI (1999) mentioned that the hydraulic system of the tractor is used to supply oil to raise and low the leveling bucket. The oil supplied by the tractor's hydraulic pump is normally delivered at 2000-3000psi (138 - 207 bar) pressure. It added the desired rate at which the bucket raises and lowers will depend on the operating speed. The faster the ground speed the faster the bucket will need to adjust. The rate at which the bucket will raise and lower is depended on the amount of oil supplied to the delivery line. El_Khatib (1992) stated that the moving capacity of laser land leveling scraper was $17.3 \mathrm{~m}^{3} / \mathrm{h}$ and field efficiency was $77 \%$ in average while the moving capacity of manual(without laser) leveling was $14.5 \mathrm{~m}^{3} / \mathrm{h}$ and field efficiency was $61 \%$ in average. The highest difference in the value of field capacity and efficiency for laser leveling was due to the use of laser control technique, which operating efficiency by improving scraper loading and swell factor. Gabber (2001) found that the energy 
requirement was decreased by increasing of land slope and forward working speed at laser technique. He added that the minimum value of field efficiency was $57 \%$ for unleveled area while after traditional was $60 \%$, but after precision land leveling were 63,65 and $75 \%$ with using $0.01,0.02$ and $0.03 \%$ slopes, respectively. El-Sayed (2004) concluded that energy values for operating the hydraulic land leveler were significantly affected by the blade size of the leveler and tractor. The energy values were higher in clay soil $\left(0.65\right.$ and $\left.0.98 \mathrm{kWh} / \mathrm{m}^{3}\right)$ comparing with sandy soil $\left(0.49\right.$ and $\left.0.75 \mathrm{kWh} / \mathrm{m}^{3}\right)$ for low and high power tractors, respectively. He added that high power tractor + large leveler requires high values of energy $\left(0.75\right.$ and $\left.0.98 \mathrm{kWh} / \mathrm{m}^{3}\right)$ comparing with low power tractor + small leveler $\left(0.49\right.$ and $\left.0.65 \mathrm{kWh} / \mathrm{m}^{3}\right)$ in sandy soil and clay soil, respectively. Zayed (2005) concluded that power values for operating the hydraulic scraper were significantly affected by the blade size of the scraper and tractor.

\section{MATERIAL AND METHODS}

A precision land leveling system consists of the following two major parts:

\section{1- Earthmoving Unit:-}

This normally consists of a standard farm tractor and a compactable simple bottomless drag scraper of a total width and dirt capacity suitable for the tractor used to pull behind.

\section{A- Tractor:}

The tractor has the following specifications:

Fait model 675Tlww, power 168 hp @2200rpm, weight 6300kg, hydraulic maximum operation pressure 190 bar and hydraulic pump flow $1161 / \mathrm{min}$.

\section{b- Scraper:}

The type of scraper being pulled will also dictate the type of valve needed. Generally, a carry all scraper requires pressure to raise the blade. However, to lower the blade on bottomless scrapers, the weight of the blade is sufficient. Therefore, a different valve is used in either situation. The K-10 Beheira and K-12 Beheira were used in the current work. The used scrapers have the following specifications:- 
Width: 3 and $3.6 \mathrm{~m}$ (10, 12 feet), Weight 770 and $1075 \mathrm{~kg}$, Capacity: 1.44 and $3.24 \mathrm{~m}^{3}$ and depth control were hydraulically.

\section{2- Laser control unit:}

\section{The transmitter}

A- Laser beam transmitter, which emits a rotating visible laser beam. The transmitter generates a long range rotating laser beam can be accurately and easily positioned to provide control plane $\mathrm{X}$ and $\mathrm{Y}$-axis. The transmitter, which used in the current work, has the following specifications:

- Beam visible laser.

- Operating rang $450 \mathrm{~m}$ radius.

- Rotating head speed $300,4580,900, \mathrm{rpm}$

\section{B- The receiving:}

The receiving and monitoring containing a $360^{\circ}$ laser beam receiver, which fitted on the drag scraper on top of a vertical mast of variable height to enable intercepting plain of laser light from any direction.

\section{C- The control box:}

It is the heart and brain of the control system and is mounted on tractor towing the drag scraper to obtain the power requirements.

\section{D- The hydraulic unit:}

It is essential for precision finish, a special interface package, is provided to connect laser control box, tractor and scraper the hydraulic system is designed to provide an adjustable oil flow to the blade to maintain grade in the control mode.

Hydraulics, contents of this package are:

- $\quad$ Hydro-electric control valve.

- $\quad$ Flow and pressure regulators.

- $\quad$ Micronics high pressure filter.

- $\quad$ Set of high pressure hoses.

- $\quad$ Set of special connecting electric cable and connectors.

- $\quad$ Set of supports, and mountings.

\section{E-Tractor hydraulics:}

The flow rates must be adjustable; the hydraulic system must a flow on command or closed center hydraulic system. This type of system only 
allows oil to flow when a valve has been opened. Tractors that do not have closed center hydraulic system must be modified to be compatible with the closed center laser plane system by adding an unloading valve and accumulator circuit. The circuit uses an accumulator which maintain certain volume of oil under pressure at all times to be used as the laser plane as the laser plane system needs it, either to raise or lower the mast in the indicate mode, or control the blade of the scraper.

\section{3-Measurement}

\section{A-Hydraulic tester instrument:}

Hydraulic tester instrument fixed at outlet of hydraulic pump to measure the oil pressure, temperature, oil flow rate as shown in fig (1) and hydraulic solenoid in cases of normal, raising and lowering the blade as shown in Fig. (2)

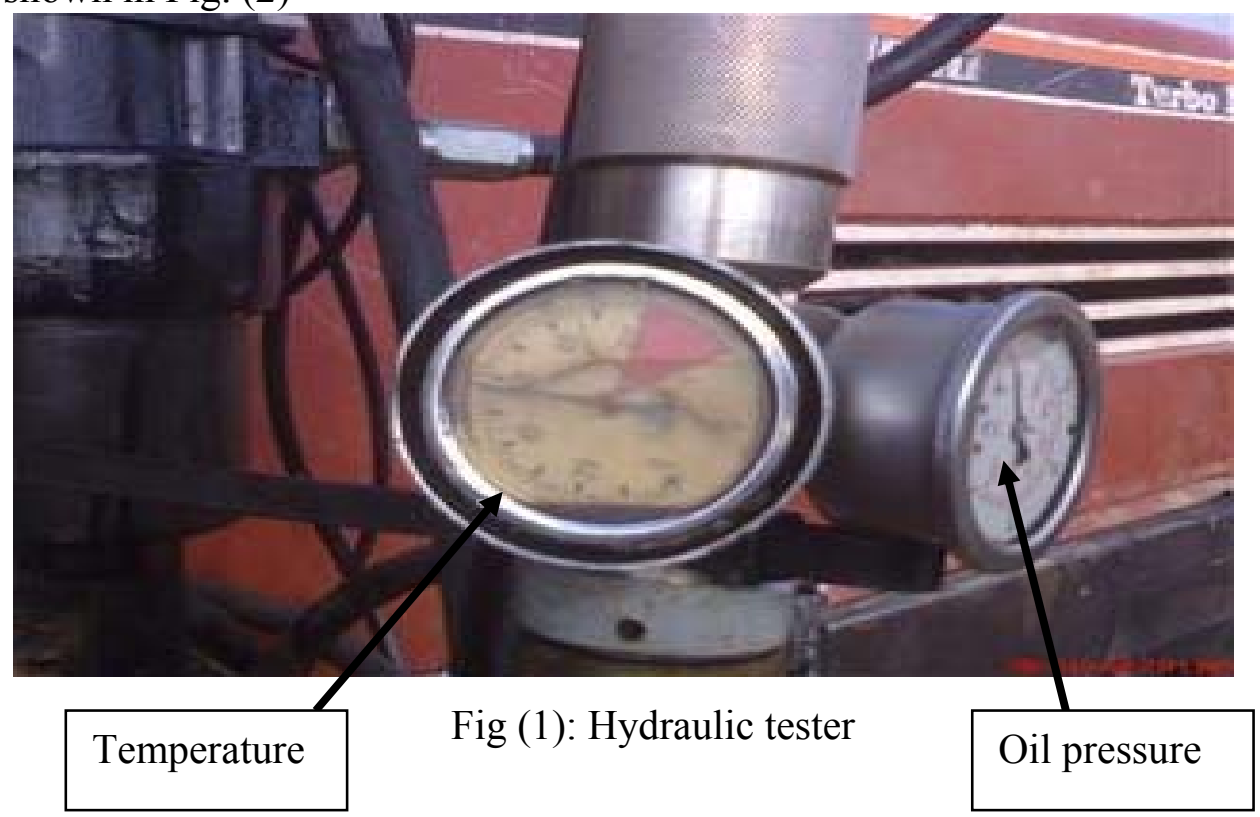




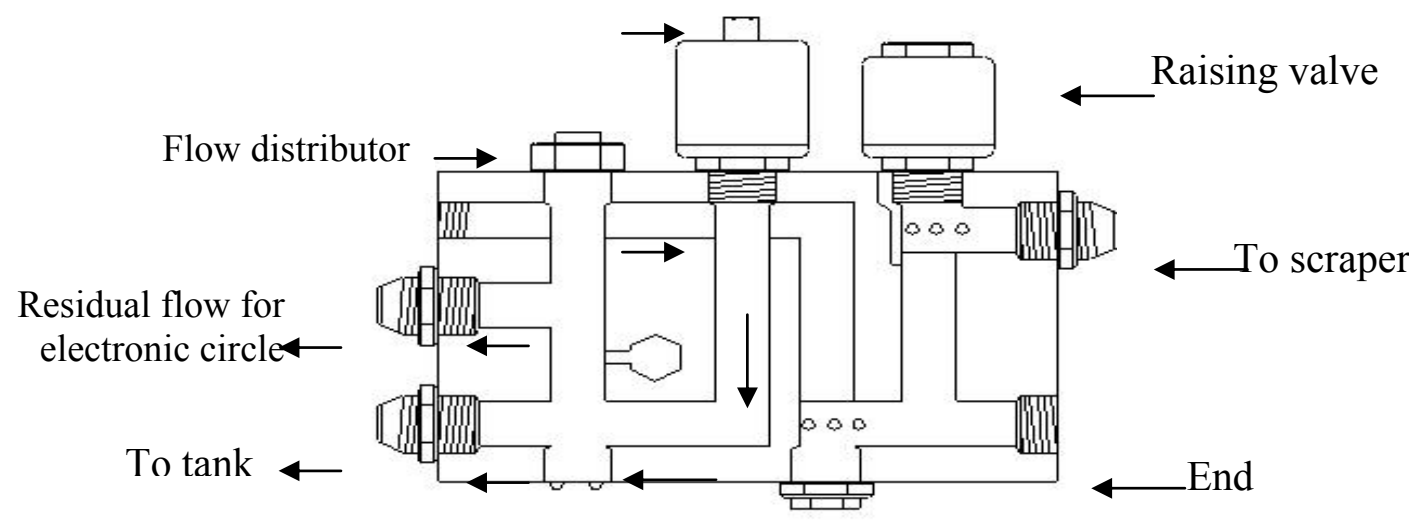

\begin{tabular}{l|l} 
Pressure re & Flator \\
A: Normal case $\downarrow$ & Flow regulator
\end{tabular}

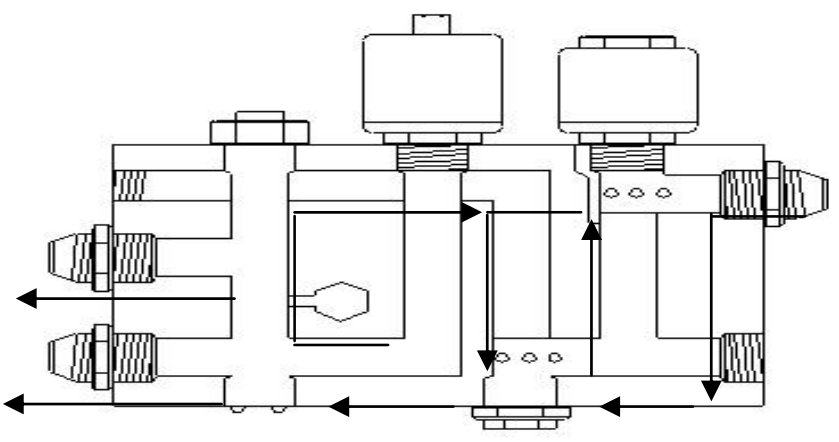

B:Raising case

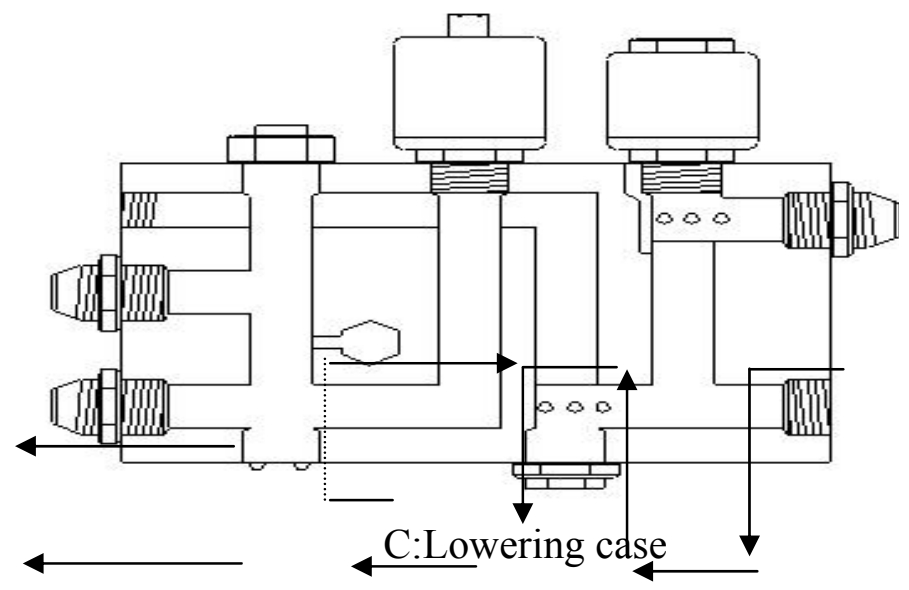

Fg.(2) : Hydraulic solenoid in cases of normal, raising and lowering the blade. 


\section{B-Methods of Calculation}

Volume of earthwork was calculated on the basis of the net square method (Jensen 1980). This method for calculating earthwork volume is based on the formula:-

$$
V_{C}=\frac{L^{2} \sum(C)^{2}}{K \sum(C+F)}
$$

$V_{C}$ : Volume of cut, $\mathrm{m}^{3}$

$$
V_{F}=\frac{L^{2} \sum(F)^{2}}{K \sum(C+F)} \ldots \ldots \ldots(2)
$$

$V_{F}:$ Volume fills, $\mathrm{m}^{3}$

$L$ : Grid spacing, $\mathrm{m}$

$C$ : Cut required at the grid point, $\mathrm{m}$

$F$ : Fill required at the grid point, $m$ and

$K$ : Dimensional constant $\quad 0.5<\mathrm{K}>1$

\section{Field Experiments}

The present work was carried out in private farm at Hoash Essa-Behera governorate during agriculture season of 2008 in clay soil. The aim of this experiment was to study the relation between the tractor hydraulics, hydro-electric valves, scraper cylinder, raising and lowering scraper blade, scraper load, and their effects on the laser land leveling efficiency and predict equations to help farm management to determine the hydraulic power need for precision land leveling by using laser technology. An area of (6 feddans) was divided into 2 plots. Every plot was leveled with different scrapers. Two scrapers were used, 3 and $3.6 \mathrm{~m}$ widths (10, 12 feets). Each plot was surveyed to calculate the volume of cut $\left(\mathrm{m}^{3}\right)$. The hydraulic oil pressure (bar) and hydraulic oil flow rate $(1 / \mathrm{min}$.) were measured with the scraper rise (every $0.5 \mathrm{~cm})$ and computed the amount of earth moving $\left(\mathrm{m}^{3}\right)$. Also, the actual scrapers capacity $\left(\mathrm{m}^{3}\right)$, 
laser land leveling field capacity $\left(\mathrm{m}^{3} / \mathrm{h}\right)$ and laser efficiency were calculated .

The physical and mechanical analyses of the soil samples were conducted at Soil and Water Research Institute, Agricultural Research Center, Giza. According to Black et al., 1965. The soil samples were taken until depth $45 \mathrm{~cm}$ to calculate the physical and mechanical properties. The results of each depth in all treatments indicated clay soil as shown in table (1).

Table (1): Physical properties of the experimental soil at Hoash Essa -

Behera governorate during agriculture season of 2008.

\begin{tabular}{|l|l|l|l|l|l|l|l|}
\hline $\begin{array}{l}\text { Depth } \\
\mathrm{cm}\end{array}$ & $\begin{array}{l}\text { Coarse } \\
\text { sand } \\
\%\end{array}$ & $\begin{array}{l}\text { Fine } \\
\text { sand } \\
\%\end{array}$ & $\begin{array}{l}\text { Silt } \\
\%\end{array}$ & $\begin{array}{l}\text { Clay } \\
\%\end{array}$ & $\begin{array}{l}\text { Texture } \\
\text { class }\end{array}$ & $\begin{array}{l}\text { Organic } \\
\text { Matter } \\
\%\end{array}$ & $\begin{array}{l}\mathrm{CaCO}_{3} \\
\%\end{array}$ \\
\hline$(0-15)$ & 5.67 & 14.90 & 18.59 & 60.84 & clay & 5.5 & 3.50 \\
\hline$(15-30)$ & 4.50 & 13.50 & 19.00 & 63.00 & clay & 5.00 & 4.00 \\
\hline$(30-45)$ & 4.20 & 14.70 & 18.60 & 62.50 & clay & 2.00 & 3.90 \\
\hline
\end{tabular}

\section{RESULTS AND DISCUSSION}

\section{1-Volume of earth moving:}

The surveying calculated data the values of sum of cut and sum of fill were $670,705 \mathrm{~cm}$ and $717,726 \mathrm{~cm}$ for each plot which leveled with 3 and $3.6 \mathrm{~m}$ scraper width respectively. Also volume of earth moving was estimated. The results of the volume of the earth moved was 81.62 and $89.06 \mathrm{~m}^{3}$ for each plot, which leveled by 3 and $3.6 \mathrm{~m}$ scraper width, respectively. The laser land leveling efficiency depends on the scraper capacity and cutting earth volume during the leveling operating. Theoretical and actual capacities were 1.44 and $1.00 \mathrm{~m}^{3}$ for scraper $3 \mathrm{~m}$ width (10 feet), respectively. The obtained working capacity of earth moved for laser scraper $3 \mathrm{~m}$ width was $10.88 \mathrm{~m}^{3} / \mathrm{h}$ with average field efficiency $69 \%$. The otherwise theoretical and actual capacities were 3.24 and $2.28 \mathrm{~m}^{3}$ for scraper $3.6 \mathrm{~m}$ width (12 feet), respectively. The capacity of earth moved for laser scraper $3 \mathrm{~m}$ width was $16.96 \mathrm{~m}^{3} / \mathrm{h}$ at average field efficiency $70.50 \%$.

Data presented in table (2), show the relation between scraper loaded $\left(\mathrm{m}^{3}\right)$ and pressure needed (bar) and hydraulic oil flow rate (lit/min.). 


\section{2-Scrapers raises and pressure needed:}

After scrapers were loaded with soil from high point's area required cutting, it's started fill soil in low points area required to fill. The scrapers to start remove soil its needs pressure to raise it. This pressure depends on the amount of earth movement to rise. Data in table (2) and Fig (3) indicated clearly that by increasing hydraulic oil pressure led to scrapers raises increase. To increase scrapers $0.5 \mathrm{~cm}$ needs pressure 6.50 and12.00 bar for scrapers 3 and $3.6 \mathrm{~m}$ withed, respectively. Also, it's clear that the maximum raise of scrapers in this experiment was $4.00 \mathrm{~cm}$ need to 52 and 110 bar for both scrapers 3 and 3.6m width, respectively. In Fig (3) both predicted equations can used in computer program to simulated which hydraulic oil pressure need for the earth movement amount and scraper raises as follow:

$$
\begin{array}{ccl}
y=5.5802 x^{1.0152}, & R^{2}=0.9792 & \text { for scrapers } 3 \mathrm{~m} \text { width } \\
\mathrm{y}==10.275 \mathrm{x}^{1.0946}, & \mathrm{R}^{2}=0.9811 & \text { for scrapers } 3.6 \mathrm{~m} \text { width }
\end{array}
$$

Table (2): Effect of scraper capacity on hoses pressure and scraper raises and lowers.

\begin{tabular}{|c|c|c|c|c|}
\hline $\begin{array}{c}\text { Amount of scraper } \\
\text { raise, }(\mathrm{cm})\end{array}$ & $\begin{array}{c}\text { The average Scraper } \\
\text { loaded, }\left(\mathrm{m}^{3}\right)\end{array}$ & $\begin{array}{c}\text { Average Pressure, } \\
\text { (bar) }\end{array}$ & $\begin{array}{c}\text { Oil flow } \\
\text { rate, (1/min.) }\end{array}$ & $\begin{array}{c}\text { Scraper loading } \\
\text { efficiency, \% }\end{array}$ \\
\hline \multicolumn{5}{|c|}{3 m scraper width } \\
\hline 0.50 & 1.00 & 6.50 & 3.20 & 69.44 \\
\hline 1.00 & 0.80 & 10.00 & 3.80 & 55.55 \\
\hline 1.50 & 0.70 & 16.00 & 4.00 & 48.61 \\
\hline 2.00 & 0.55 & 20.00 & 8.50 & 38.19 \\
\hline 2.50 & 0.42 & 28.00 & 12.00 & 29.17 \\
\hline 3.00 & 030 & 35.00 & 15.00 & 20.33 \\
\hline 3.50 & 0.18 & 42.00 & 16.50 & 12.50 \\
\hline 4.00 & 0.10 & 52.00 & 18.50 & 6.94 \\
\hline \multicolumn{5}{|c|}{3.6 m scraper width } \\
\hline 0.50 & 2.28 & 12.00 & 9.50 & 70.37 \\
\hline 1.00 & 2.05 & 20.00 & 14.80 & 63.27 \\
\hline 1.50 & 1.70 & 30.00 & 20.00 & 52.47 \\
\hline 2.00 & 1.45 & 42.00 & 23.50 & 44.75 \\
\hline 2.50 & 1.10 & 60.00 & 27.00 & 33.95 \\
\hline 3.00 & .0 .80 & 72.00 & 31.00 & 24.69 \\
\hline 3.50 & 0.45 & 95.00 & 34.50 & 13.89 \\
\hline 4.00 & 0.15 & 110.00 & 38.00 & 4.63 \\
\hline
\end{tabular}




\section{3-The relation between pressure and oil flow rate:}

When the system is in the control mode the oil in the blade circuit flows through the solenoid valve, the control box activate from the valve when received signals which sends oil to the either raise or lower the grade cylinder. Data in table (2) and Fig (4) showed that, the increasing pressure needs to increase oil flow rate for scraper $3 \mathrm{~m}$ width by increase pressure from 6.5 bar to 52 bar then the oil flow rate increasing from 3.2 $1 / \mathrm{min}$. to $18.5 \mathrm{l} / \mathrm{min}$., also for scraper $3.6 \mathrm{~m}$ width by increasing pressure from 12 bar to 110 bar the oil flow rate increased from $9.51 / \mathrm{min}$. to 38 $1 / \mathrm{min}$. The results and calculated data was presented that, every $1 \mathrm{~m}^{3}$ soil needs to 52 bar pressure and $18.51 / \mathrm{min}$. oil rate to fill area $25 \mathrm{~m}^{2}$ with depth $4 \mathrm{~cm}$, the area can be increased by decreasing the depth of fill. In Fig (4) both predicted equations can used in computer program to simulated which hydraulic oil pressure need for oil flow rate as follow:

$$
\begin{gathered}
y=9.4508 x^{0.6637}, \quad R^{2}=0.9992 \text { for scrapers } 3 \mathrm{~m} \text { width } \\
\mathrm{y}=2.31781 \mathrm{x}^{0.9631}, \mathrm{R}^{2}=0.8795 \text { for scrapers } 3.6 \mathrm{~m} \text { width }
\end{gathered}
$$

\section{4-Laser land leveling efficiency:}

The laser land leveling efficiency depends on the scraper capacity and cutting earth volume during the leveling operation. The values of field capacity and efficiency for laser land leveling scraper were due to use of laser control technique which in principle increases operating efficiency by improving scraper loading. To complete to determine laser land leveling efficiency at first how much earth was cut using full capacity of scraper and then how much earth volume was required to cut. Accordingly to the hydro - electric valve transmit hydraulic flow pulses to scraper cylinder to raise or lower scraper blade to correct its position in the relation to plain of rotating laser light when properly set, while scraper is moved up and down the field repeated correction for its blade level, will cause the blade to cut in the soil or raise above ground and drop part or all of its load while it maintains its linear attitude parallel to plain of laser light. After one or few passes above, procedure will cause the ground surface to become perfectly leveled and parallel to rotating plain of laser light. Data in table (2) and Fig. (5) indicated that the scraper capacity efficiency increased by increasing cutting depth, it was increased by increasing cutting depth from 0.5 to $4 \mathrm{~cm}$ for 3 and 3.6 meter scrapers 
width by percentage ratios from 6.94 to $69.44 \%$ and 4.63 to $70.73 \%$, respectively.

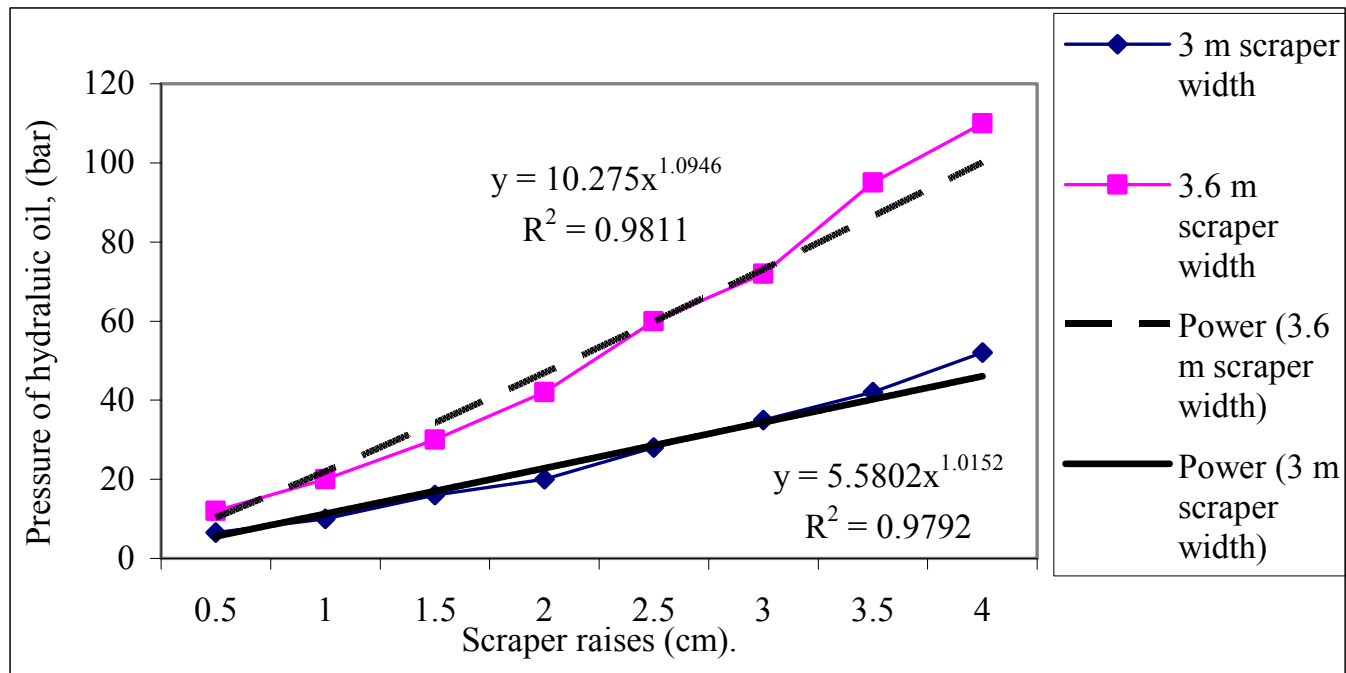

Fig. (3) Effect of amount scrape raises on pressure needed

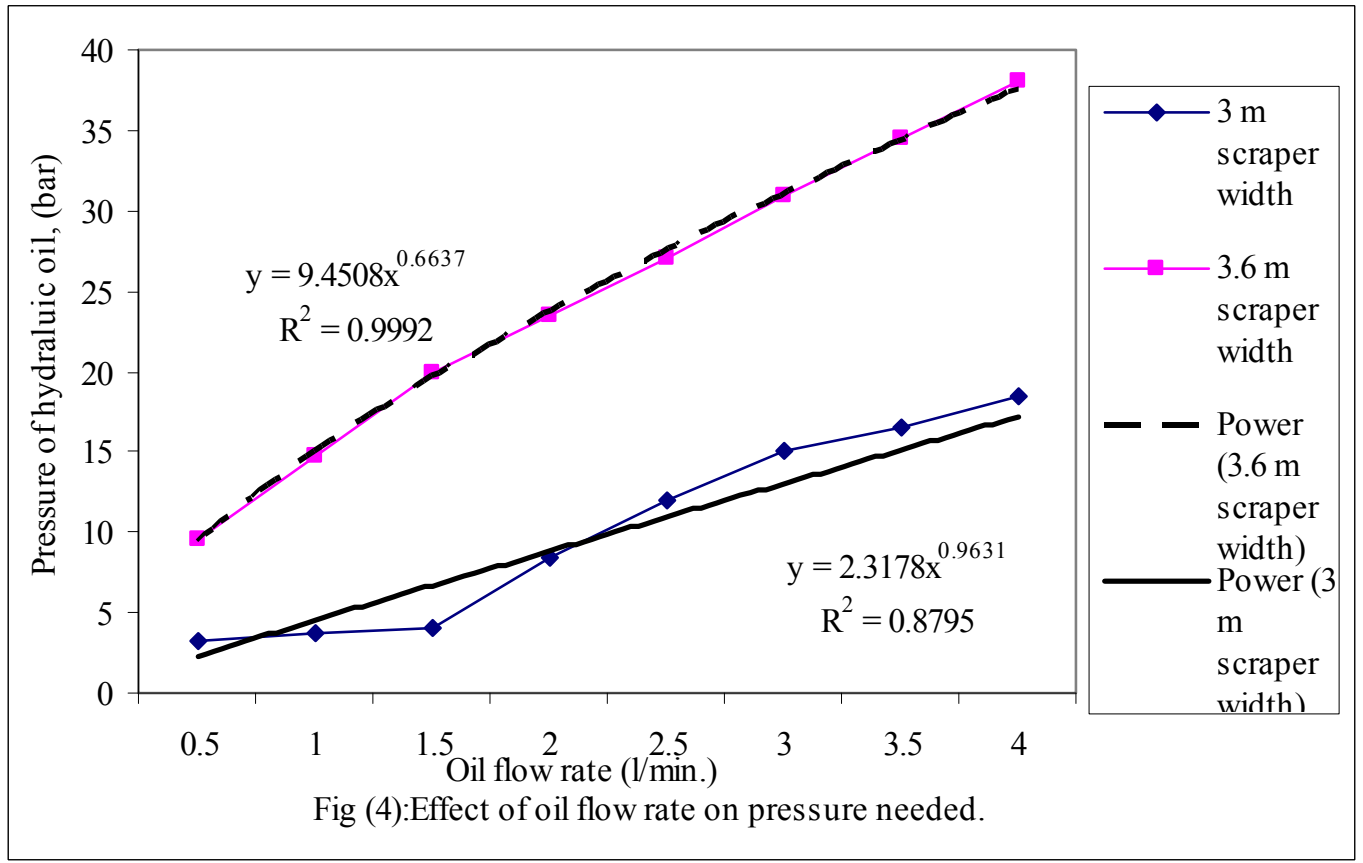




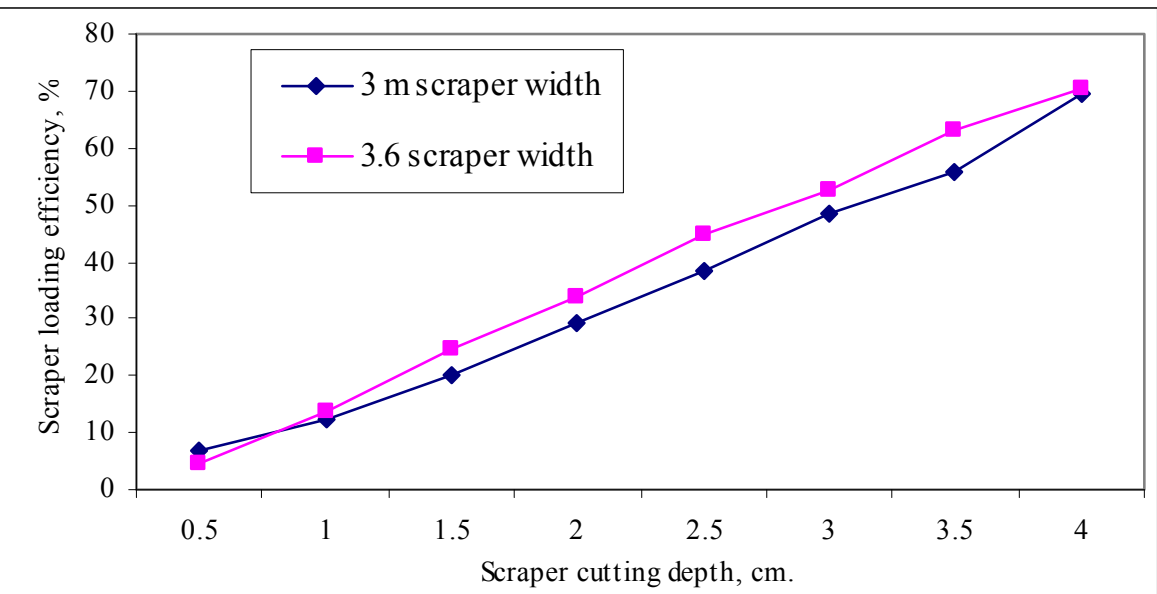

Fig (5) Effect of cutting depth on scraper loading efficiency.

\section{CONCLUSION}

Because the flow rates must be adjustable, the hydraulic system must be "flow on command" or closed center hydraulic system. From the above results and discussion, it can be concluded that:

1- $\quad$ Actual scrapers loaded were 69 and $70.50 \%$ for 3 and $3.6 \mathrm{~m}$ scraper width respectively.

2- $\quad$ Maximum pressure needed to raise scraper was 52 and 110 bar for 3 and $3.6 \mathrm{~m}$ scraper width respectively.

3- Maximum oil flow rate was 18.5 and $38.001 / \mathrm{min}$ for 3 and $3.6 \mathrm{~m}$ scraper width respectively.

4- Scrapers field capacity was 10.88 and $16.96 \mathrm{~m}^{3} / \mathrm{h}$ for 3 and $3.6 \mathrm{~m}$ scraper width respectively.

5- $\quad$ The scraper capacity efficiency increased by increasing cutting depth, it was increased from 6.94 to $69.44 \%$ by increasing cutting depth from 0.5 to $4 \mathrm{~cm}$ for 3 meter scraper width also it was increased from 4.63 to $70.73 \%$ by increasing cutting depth from 0.5 to $4 \mathrm{~cm}$ for 3.6 meter scraper width.

6- $\quad$ Every one $\mathrm{m}^{3}$ of soil needed to 52 bars of oil pressure and 18.5 $1 /$ min of oil flow rate to fill area $25 \mathrm{~m}^{2}$ with $4 \mathrm{~cm}$ depth.

Obtained predicted equations from the curves help engineering computer designers to make decision easily and determine the actual hydraulic oil pressure and oil flow rate to move the amount of earth. 


\section{REFERENCES}

Black, C. A., D. D. Evans, L. E. Ensminger, and R. C. Dinauer, (1965). Methods of analysis (part 1). Am. Soc. of Agron., Inc. Publ. Madison, Wisc., U.S.A.

CPTI (1999). Manual for Laser Leveling. Cambodia Project Tractor Implement, International Rice Research Institute. Agric. Eng. Division LOSBANOS, LAGUNA, PHILIPPINS. pp 7-8.

El-Khatib, S. I. (1992). Effect of degree of accuracy of land leveling on performance and efficiency of some farm machinery. M. Sc. Thesis Faculty of Agric. Ain Shams Univ., Egypt. Pp 50-51.

El-Hammamy, A. A. (1988). Precision land leveling: An effective tool from on-farm water management. First conference on irrigation improvement Cairo, Egypt.

El-Sayed, S. G.(2004). A study on Increasing the Laser Unit Efficiency under Egyptian Condition. M. Sc. Thesis Fac. of Agric., Zagazig Univ., Egypt. Pp 56-57.

Gabber, K. A. E. (2001). Precision land leveling by using laser technology under the conditions of Fayoum Governorate. M. Sc. Thesis, Soils and Water Dept., Fac. of Agric. at Fayoum, Cairo Univ., Egypt. Pp 60-61.

Jensen, M. E. (1980). Design and operation of farm irrigation systems. The Transaction of Amer. Sec. Agric. Eng. Vol 23.

Mostafa, M.M., EL-Gindy, A., Saif-Elyazal M.N. and El-Khatib, S.I. (1993). Laser land leveling efficiency and power requirements. International conference on technological techniques for handling agricultural products 5-10 April 1993. Cairo Uni.Cairo, Egypt pp 5875.

Zayed. M. F. (2005). Modification of laser technology in farm application. M. Sc.Thesis, Fac. of Agric., Mansoura Univ., Egypt. pp 83-84. 


\section{الملخص العربي \\ تحديد العوامل الهيروليكية المناسبة للتحكم فى رفع وخفض قصابيات الليزر}



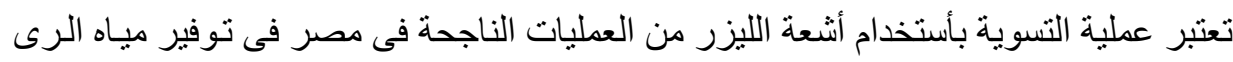

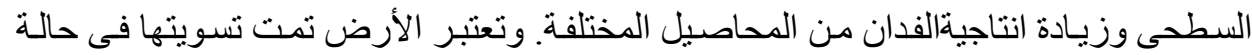



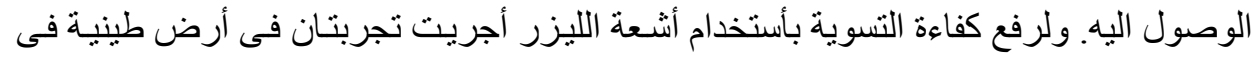

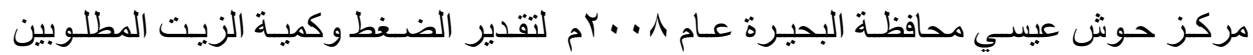

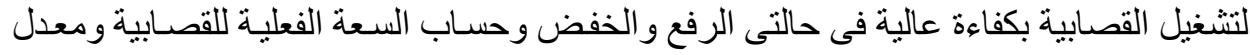

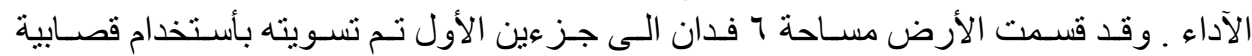

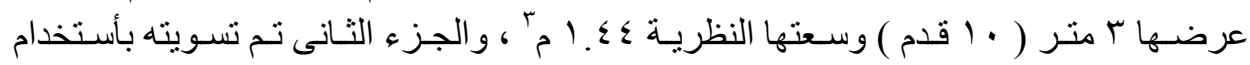

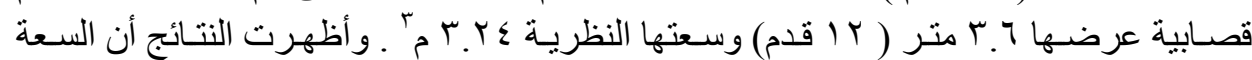

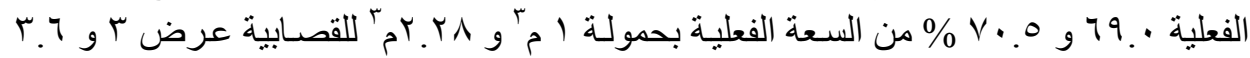

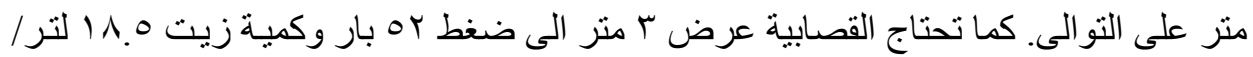

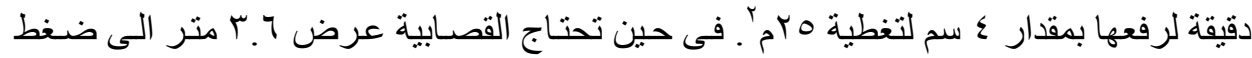



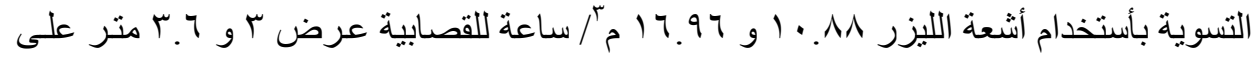

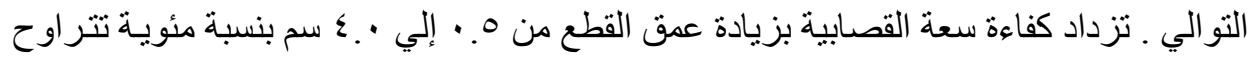



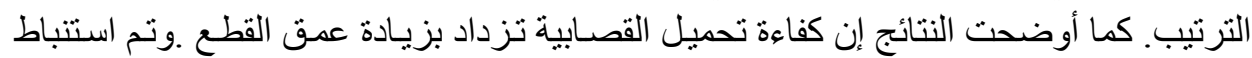



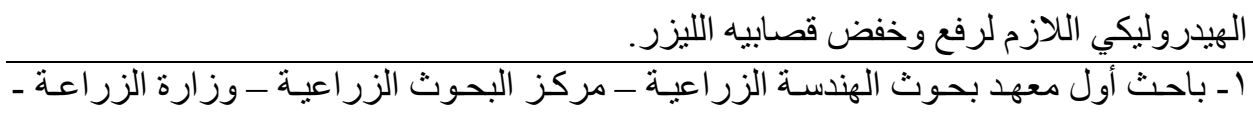

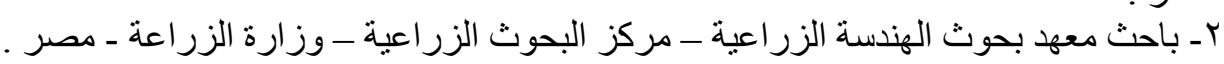

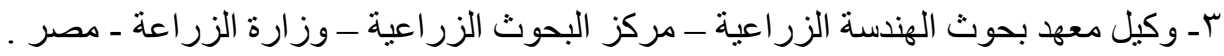

